\title{
TINGKAT PENGETAHUAN AKSEPTOR KB TENTANG METODE KONTRASEPSI JANGKA PANJANG DENGAN KEIKUTSERTAAN TERHADAP METODE KONTRASEPSI JANGKA PANJANG
}

\section{Knowledge Level of KB Acceptors About Long Term Contraception Method with Participation of Long Term Contraception Method}

\author{
${ }^{1}$ Ni Gusti Ayu Pramita Aswitami, ${ }^{2}$ Pande Putu Indah Purnamayanthi, ${ }^{3}$ Ni Putu Mirah Yunita \\ Udayani, ${ }^{4}$ I Gst Ayu Agung Prameswari \\ ${ }^{1-4}$ Program Studi Kebidanan, STIKES Bina Usada Bali, Badung, Bali, Indonesia \\ Korespondensi : tami_chant@yahoo.com
}

\begin{abstract}
ABSTRAK
Keluarga Berencana (KB) menurut World Health Organisation (WHO) adalah tindakan yang membantu individu atau pasangan suami istri untuk menghindari kelahiran yang tidak diinginkan, mendapatkan kelahiran yang diinginkan, mengatur interval kelahiran, mengontrol waktu saat kelahiran dalam hubungan dengan umur suami dan istri, menentukan jumlah anak dalam keluarga. Salah satu faktor yang memengaruhi keikutsertaan sebagai akseptor metode kontrasepsi jangka panjang adalah pengetahuan suami istri mengenai kontrasepsi tersebut. Tujuan penelitian ini adalah untuk mengetahui hubungan tingkat pengetahuan akseptor KB tentang metode kontrasepsi jangka panjang (MKJP) dengan keikutsertaan MKJP di banjar Air Kuning Kecamatan Jembrana. Penelitian ini menggunakan rancangan non eksperimen dengan pendekatan kuantitatif. Desain penelitian yang digunakan adalah penelitian analitik dengan pendekatan cross sectional yaitu melakukan pengumpulan data dalam satu waktu dan tiap subyek penelitian diobservasi sekali saja. Hasil uji statistik chi square $\left(X^{2}\right)$ didapatkan hasil hitung untuk tingkat pengetahuan akseptor KB tentang metode kontrasepsi jangka panjang (MKJP) sebesar 61,267 dengan tingkat kemaknaan 95\% dengan nilai $p<0.05$ yang artinya terdapat hubungan yang signifikan antara tingkat pengetahuan akseptor KB tentang metode kontrasepsi jangka panjang (MKJP) dengan keikutsertaan terhadap MKJP. Disarankan kepada petugas kesehatan untuk memberikan edukasi lebih banyak tentang kontrasepsi jangka panjang sehingga akseptor KB MKJP akan bertambah untuk mengontrol kehamilan dengan baik.
\end{abstract}

Kata Kunci: akseptor, metode kontrasepsi jangka panjang, pengetahuan

\begin{abstract}
Family Planning (KB) according to the World Health Organization (WHO) is an action that helps individuals or married couples to avoid unwanted births, get the desired birth, regulate the birth interval, control the time at birth in relation to the age of husband and wife, determine the number of children in the family. One of the factors that influence participation as acceptors of long-term contraceptive methods is the knowledge of husband and wife about contraception. The purpose of this study was to determine the corrrelatiions Knowledge Level of KB Acceptors About Long Term Contraception Method with Participation of Long Term Contraception Method in the Air Kuning Village, Jembrana District. This study used a nonexperimental design with a quantitative approach. The research design used was analytical research with a cross sectional approach, which was to collect data at one time and each research subject was observed only once. The results of the chi square statistical test (X2) obtained the calculation results for the level of family planning acceptors 'knowledge of the long-term contraceptive method (MKJP) of 61.267 with a significance level of 95\% with a $p$ value $<0.05$, which means that there is a significant correlationt between the level of family planning acceptors' knowledge about the contraceptive method. long-term (MKJP) with participation in MKJP. It is recommended that health workers provide more education about long-term contraception so that MKJP family planning acceptors will increase to control pregnancy well.
\end{abstract}

Keywords: acceptors, long-term contraceptive methods, knowledge 


\section{PENDAHULUAN}

Indonesia merupakan sebuah negara berkembang termasuk Bali dengan jumlah penduduk sebanyak 4.152.800 jiwa dengan luas wilayah bali $5.636,66 \mathrm{~km}^{2}$ pada akhir tahun 2015. Masalah yang terdapat di berbagai daerah adalah laju pertumbuhan penduduk yang relatif masih tinggi. Laju pertumbuhan penduduk ditentukan oleh kelahiran dan kematian dengan adanya perbaikan pelayanan kesehatan menyebabkan tingkat kematian rendah, sedangkan tingkat kelahiran tetap tinggi, hal ini adalah penyebab utama ledakan penduduk (BKKBN, 2009). Upaya yang dilakukan untuk menekan laju pertumbuhan penduduk yaitu dengan program pelayanan keluarga berencana. Pelayanan KB yang dimaksudkan untuk menjaga kesehatan reproduksi dan meningkatkan kualitas hidup masyarakat. Dengan demikian diharapkan tidak ada kehamilan yang tidak diinginkan (Kusumaningrum, 2009).

Beberapa data telah menunjukkan selama ini gerakan KB nasional telah berhasil mendorong penongkatan peran serta masyarakat dalam membangun keluarga kecil yang makin mandiri tetapi masih belum merata dengan masih kurangnya peserta KB dengan metode kontrasepsi jangka panjang (BKKBN, 2012). Factorfaktor yang menyebabkan pasangan usia subur (PUS) masih ada yang belum menjadi peserta KB adalah masih rendahnya kualitas pelayanan $\mathrm{KB}$, terbatasnya alat kontrasepsi dan masih rendahnya komunikasi,informasi dan edukasi tentang pelayanan $\mathrm{KB}$ oleh tenaga kesehatan ke masyarakat (Pinem, 2009).

Berdasarkan data dari Dinas Kesehatan Kabupaten Jembrana Puskesmas dengan pencapaian peserta KB aktif baik MKJP maupun Non MKJP yang paling tinggi adalah Puskesmas II Melaya sebanyak 8.064 orang $(18.08 \%)$, sedangkan puskesmas dengan pencapaian peserta KB Aktif yang paling rendah adalah Puskesmas II Jembrana sebanyak 2.908 orang $(6.5 \%)$. Berdasarkan data yang diperoleh dari Puskesmas II Jembrana dan bidan wilayah puskesmas II Jembrana, didapatkan data peserta KB Aktif baik MKJP maupun Non MKJP yang paling tinggi ada di Banjar
Munduk Desa Air Kuning sebanyak 175 orang $(83.3 \%)$ sedangkan yang paling rendah ada di Banjar Air kuning sebanyak 167 orang $(79.2 \%)$. Penggunaan metode kontrasepsi jangka panjang (MKJP) di Banjar Munduk Desa Air Kuning rendah karena masyarakat atau pasangan usia subur kurang memahami dan mengerti tentang metode kontrasepsi jangka panjang (MKJP). Pemahaman masyarakat terbatas bahwa MKJP harus operasi dan itu menimbulkan rasa takut yang tinggi sehingga alasan ini peserta MKJP pada daerah ini rendah.

\section{TUJUAN PENELITIAN}

Tujuan dalam penelitian ini adalah untuk mengetahui Hubungan Tingkat Pengetahuan Akseptor KB tentang Metode Kontrasepsi Jangka Panjang (MKJP) dengan Keikutsertaan MKJP di Banjar Air Kuning Kecamatan Jembrana.

\section{METODE PENELITIAN}

Desain

Jenis penelitian yang digunakan pada penelitian ini penelitian analitik yaitu untuk melihat hubungan (korelasi) antara tingkat pengetahuan akseptor $\mathrm{KB}$ tentang metode kontrasepsi jangka panjang dengan keikutsertaan MKJP di Banjar Air Kuning Kecamatan Jembrana dengan pendekatan cross sectional.

\section{Populasi dan Sampel}

Populasi dalam penelitian ini berjumlah 167 orang. Teknik pengambilan sampel yang dilakukan pada penelitian ini adalah simple random sampling. Kriteria yang digunakan dalam pengambilan sampel menggunakan kriteria inklusi dan kriteria eksklusi sehingga besaran sampel dalam penelitian ini adalah 69 orang.

\section{Tempat dan Waktu Penelitian}

Lokasi penelitian dilakukan di Banjar Air Kuning Kecamatan Jembrana. Waktu penelitian dilaksanakan mulai dari tanggal 1 Agustus 2018 sampai tanggal 31 Agustus 2018. 
Ni Gusti Ayu Pramita Aswitami, dkk: Tingkat Pengetahuan Akseptor KB Tentang Metode Kontrasepsi Jangka Panjang Dengan Keikutsertaan Terhadap Metode Kontrasepsi Jangka Panjang

\section{Instrumen dan Prosedur Pengukuran}

Alat bantu yang digunakan untuk pengumpulan data adalah kuesioner pengetahuan tentang metode kontrasepsi jangka panjang yang telah diuji valid dan reliable. Prosedur pengukuran dilakukan dengan menyebarkan kuesioner yang kemudian diisi oleh responden. Data yang dikumpulkan adalah tingkat pengetahuan akseptor KB tentang metode kontrasepsi jangka panjang dan data keikutsertaan MKJP. Analisa Data

Analisis data menggunakan SPSS versi 23. Data yang dianalisis adalah data univariat dan bivariat untuk melihat hubungan antara tingkat pengetahuan tentang metode kontrasepsi jangka panjang. Analisis bivariate menggunakan uji statistik (Chi Square) $\left(\mathrm{X}^{2}\right)$ yaitu dengan kemaknaan 95\%. Bila hasil $p$ $<0.05$ berarti ada hubungan yang signifikan antara tingkat pengetahuan akseptor $\mathrm{KB}$ tentang keikutsertaan terhadap MKJP.

\section{HASIL PENELITIAN}

Hasil penelitian sebagai berikut:

\section{Tabel 1}

Hubungan Tingkat Pengetahuan Akseptor

KB Tentang Metode Kontrasepsi Jangka

Panjang (MKJP) Dengan Keikutsertaan Terhadap MKJP $(n=69)$

\begin{tabular}{|c|c|c|c|c|}
\hline Variabel & \multicolumn{3}{|c|}{ Pengetahuan } & \multirow{3}{*}{ e } \\
\hline \multirow{2}{*}{$\begin{array}{c}\text { Keikutsertaan } \\
\text { MKJP }\end{array}$} & Baik & Cukup & Kurang & \\
\hline & $f(\%)$ & $\mathrm{f}(\%)$ & $f(\%)$ & \\
\hline MKJP & $\begin{array}{c}9 \\
(13,1)\end{array}$ & $1(1,4)$ & $0(0)$ & 0.000 \\
\hline Non-MKJP & $0(0)$ & $\begin{array}{c}23 \\
(33,3)\end{array}$ & $\begin{array}{c}36 \\
(52,2)\end{array}$ & \\
\hline
\end{tabular}

Hasil analisis Hubungan tingkat pengetahuan akseptor $\mathrm{KB}$ tentang MKJP dengan keikutsertaan terhadap MKJP menunjukkan paling banyak yaitu 36 orang dari total responden yang memiliki pengetahuan kurang, (100\%) diantaranya adalah mereka yang tidak menggunakan MKJP, setelah dilakukan uji statistik chi square $\left(X^{2}\right)$ didapatkan hasil hitung untuk tingkat pengetahuan akseptor $\mathrm{KB}$ tentang metode kontrasepsi jangka panjang (MKJP) sebesar 61,267 dengan tingkat kemaknaan 95\% dengan nilai $p<0.05$. Jika dilihat pada kolom Asymp.Sig, terdapat probabilitas sebesar 0.000 yang jauh lebih kecil dari 0.05. Maka berdasarkan hasil tersebut maka $\mathrm{H}_{0}$ ditolak berarti $\mathrm{H}_{1}$ diterima dengan signifikan yang bermakna adanya hubungan antara tingkat pengetahuan akseptor $\mathrm{KB}$ tentang metode kontrasepsi jangka panjang (MKJP) dengan keikutsertaan terhadap MKJP.

\section{PEMBAHASAN}

Kelompok responden MKJP memiliki pengetahuan baik yang lebih tinggi $(100 \%)$ daripada kelompok responden non MKJP. Hal tersebut kemungkinan dikarenakan kurangnya informasi tentang metode kontrasepsi jangka panjang daripada kelompok pengguna MKJP. Kurangnya pengetahuan tentang kontrasepsi jangka panjang pada kelompok non MKJP dapat menunjukkan bahwa variabel tersebut merupakan faktor yang mempengaruhi rendahnya keikutsertaan pengguna MKJP pada PUS. Hasil penelitian ini memiliki kesamaan dengan penelitian Marhaeni (2000), yang menyatakan bahwa ada pengaruh yang bermakna antara pengetahuan dengan pemilihan alat kontrasepsi oleh akseptor KB. Menurut asumsi peneliti pengetahuan akseptor KB sangat erat kaitannya terhadap pemilihan alat kontrasepsi, karena dengan adanya pengetahuan yang baik terhadap metode kontrasepsi tertentu akan merubah cara pandang akseptor dalam menentukan kontrasepsi yang paling sesuai dan efektif digunakan sehingga membuat pengguna $\mathrm{KB}$ lebih nyaman terhadap kontrasepsi tersebut.

Pengetahuan yang baik akan alat kontrasepsi dapat mengindari kesalahan dalam pemilihan alat kontrasepsi yang paling sesuai bagi pengguna itu sendiri. Penelitian ini sejalan dengan penelitian sebelumnya yang dilakukan oleh Rotie et al. (2015), yaitu sebanyak 67 orang $(100 \%)$ diantaranya adalah mereka yang tidak menggunakan MKJP, dan dari hasil uji statistik chi square terdapat nilai $(p)$ sebesar 0.000 yang jauh lebih kecil dari 0.05 menunjukkan bahwa terdapat hubungan antara pengetahuan responden dengan penggunaan metode kontrasepsi jangka panjang. Berdasarkan hasil uji regresi berganda tingkat pengetahuan akseptor KB merupakan salah 
satu faktor yang memiliki pengaruh empat kali lebih besar terhadap keikutsertaan responden untuk memilih MKJP dari pada faktor lainnya yang dianggap sebagai perancu dalam penelitian ini. Sesuai pendapat teori yang mengatakan bahwa pengetahuan merupakan faktor predisposisi terhadap perubahan perilaku yang mengarahkan pada tingkat status kesehatan termasuk perilaku akseptor KB tentang pemakaian alat kontrasepsi yang optimal atau keberhasilan program KB.

Menurut Marhaeni (2000), semakin luas pengetahuan yang dimiliki seseorang khususnya pengetahuan tentang MKJP, kecenderungan untuk memilih MKJP semakin meningkat, demikian sebaliknya pengetahuan yang masih kurang terkait kontrasepsi jangka panjang baik itu tentang efek samping, jenis jenis MKJP, keuntungan dan kerugian dari MKJP membuat seseorang mudah terpengaruh oleh informasi yang salah mengenai MKJP sehingga tidak menimbulkan minat untuk memilih MKJP. Pengetahuan akseptor KB tentang MKJP yang kurang merupakan salah satu penyebab rendahnya Keikutsertaan MKJP di Banjar Air Kuning. Pengetahuan responden tentang kontrasepsi di kelompok akseptor KB non MKJP sebagian besar lebih rendah bila dibandingkan tingkat pengetahuan responden di kelompok pengguna MKJP. Hal tersebut kemungkinan dikarenakan kurangnya informasi tentang kontrasepsi jangka panjang. Kurangnya pengetahuan tentang kontrasepsi jangka panjang pada non MKJP dapat menunjukkan bahwa variabel tersebut merupakan faktor yang mempengaruhi rendahnya keikutsertaan pengguna MKJP.

Penelitian ini sama dengan penelitian yang dilakukan oleh Dewi \& Notobroto (2014), akseptor yang mempunyai pengetahuan tinggi lebih besar peluangnya untuk menggunakan (LAPMs) (long acting and permanent contracrptive methods) atau MKJP dibandingkan dengan mereka yang mempunyai pengetahuan yang rendah. Pengetahuan yang kurang dapat mempengaruhi informasi yang didapatkan baik melalui diskusi maupun promosi. Hal ini sejalan dengan peneliti Gebremariam \& Addisie (2014), penelitiannya menunjukkan sebagian besar peserta KB tidak mampu mengidentifikasi jenis kontrasepsi permanen sebagai metode kontrasepsi. Penyebabnya adalah kekurangan informasi dasar tentang bagaimana metode ini bekerja dan bagaimana mereka dapat menggunakannya.

\section{KESIMPULAN}

Implikasi

Keikutsertaan responden terhadap MKJP sangat dipengaruhi oleh tingkat pengetahuan, tingkat pengetahuan memiliki pengaruh empat kali lebih besar mempengaruhi keikutsertaan MKJP daripada faktor lainnya. Semakin tinggi tingkat pengetahuan seseorang tentang MKJP, maka kecendrungan seseorang untuk memilih MKJP semakin meningkat, demikian sebaliknya pada hasil penelitian ini keikutsertaan MKJP masih kurang di Banjar Air Kuning yang disebabkan oleh tingkat pengetahuan responden yang masih kurang tentang MKJP.

\section{Keterbatasan}

Keterbatasan pada penelitian ini adalah adanya penggunaan istilah medis pada kuesioner yang sulit dipahami oleh para responden ketika mengisi kuesioner sehingga peneliti menjelaskan kembali isian kuesioner menggunakan Bahasa yang lebih mudah dipahami.

\section{DAFTAR PUSTAKA}

BKKBN. (2009). Pedoman pelayanan KB dalam jaminan kesehatan masyarakat.

BKKBN. (2012). Pelayanan Kontrasepsi.

Dewi, P. H. C., \& Notobroto, H. B. (2014). Rendahnya Keikutsertaan Pengguna Metode Kontrasepsi Jangka Panjang Pada Pasangan Usia Subur Di Polindes Tebalo Kecamatan Manyar Kabupaten Gresik. Biometrika Dan Kependudukan, 3, 66-72.

Gebremariam, A., \& Addisie, A. (2014). Journal Reproductive Health. 11 (24), pp 1. Journal Reproductive Health. 11 (24), Pp 1.

Kusumaningrum, R. (2009). Faktor-Faktor yang Mempengaruhi Pemilihan Jenis Kontrasepsi yang Digunakan Pasangan Usia Subur. UNDIP.

Marhaeni, S. (2000). Faktor-faktor yang Berhubungan Dengan Penggunaan Implant di Desa Parit Kecamatan 
Ni Gusti Ayu Pramita Aswitami, dkk: Tingkat Pengetahuan Akseptor KB Tentang Metode Kontrasepsi Jangka Panjang Dengan Keikutsertaan Terhadap Metode Kontrasepsi Jangka Panjang

Indralaya Utara Kabupaten Ogan Ilir. Penelitian Medias Imroni, Nur Alam Fajar, Fatmalina Febri.

Pinem, S. (2009). Kesehatan Reproduksi dan Kontrasepsi. Trans Info Media.

Rotie, N., Tombokan, S., \& Adam, S. (2015). Hubungan Pengetahuan Dan Tingkat Pendidikan Ibu Dengan Penggunaan Metode Kontrasepsi Efektif Terpilih. Jurnal Ilmiah Bidan, 3(1), 91646. 